\title{
Saskatchewan's First Nesting Record of the Whip-Poor-Will
}

\author{
by MAURICE G. STREET, Nipawin, Sask.
}

Any person who has heard the song of the Whip-poor-will, throughout its wide breeding range, could hardly fail to recognize the oft repeated phrase, resembling its name, Whippoor-will. However, its being a bird of the evening shadows and the darkened glades has resulted in the Whip-poor-will being more often heard than seen.

There are, in Saskatchewan, a number of reports of the Whip-poorwill being heard, but reports of its being seen seem almost entirely lacking. Mitchell (1) records a specimen collected at Winton, east of Prince Albert, July 21, 1919, and tells of others being heard at Kamsack, ley. Houston (2) states "The Whippoor-will is now only a rare straggler." He reports the Whip-poor-will as being heard calling near Rousay Lake, 1889; at Crescent Lake, three times prior to 1900 and in the Assiniboine Valley in 1938; another was at Yorkton during the same year, and it was heard calling at Good Spirit Lake in July 1943. Ronald and Donald Hooper report one as being heard near Somme, Sask., in 1924 (3).

On or about June 11, 1956, $\mathrm{Mr}$. and Mrs. J. A. Nevins heard a Whippoor-will calling near their farm home, 7 miles east and 5 miles north of Nipawin. Mrs. Nivens, being familiar with the call of the Whippoor-will in Eastern Manitoba some years before, recognized the call at once. The bird continued to call the next few evenings, and this was reported to Billy and Walter Matthews. On the evening of June 18, the Matthews visited the area and were rewarded with hearing the Whippoor-will, apparently at its best, calling continuously for several hours with only brief pauses.

Together with the Matthews, this writer visited the same area the next evening, June 19, arriving there shortly after 8:00 p.m. (Mountain Standard). From the Mevins' yard we heard the Whip-poor-will's first call at 8:40, which appeared to come from a Jackpine ridge some 200 yards south. We drove to this ridge, and the bird was again heard calling a short distance to the west. Walking in the direction of its call we flushed the Whip-poor-will after proceeding some 40 yards. This was the first sight (and sound) of the bird for the writer who has been a bird watcher for thirty-four years; it was a "lifetime first" also for Mr. Matthews who has watched birds for forty years in the Carrot River Valley. The distinct white areas on either side of the tail as it flew silently away in the gathering dusk proved the bird to be a male. The bird alighted a short distance away, and by walking in the direction of its call we again flushed it. This act was repeated several times, until at last we had followed the bird in almost a complete circle to the place where we had originally flushed the Whip-poor-will. After being pestered with hordes of misquitoes, we left the area at 9:45 p.m. with the bird still calling.

On June 27, Mr. Roy G. Lanz and I again visited the area. Arriving at 6:00 p.m. we walked directly to the spot where we had flushed the Whippoor-will on June 19. We paused, then walked a few yards to the highest point of the ridge. Pausing there, we surveyed the area from our vantage point. Here seemed an ideal place for a nesting site, according to what I had read of nests found in the Eastern United States. I had taken only a few steps when a female Whip-poor-will flushed almost beneath my feet, she had been brooding two eggs, laid on a few dead leaves and pine needles. I was amazed at the ease with which the eggs could be seen on this lightly treed, gently sloping, well drained hillside. Lanz, standing fifty feet farther up the ridge, saw the female flush and could see the eggs at that distance.

The two eggs, creamy white, sparcely spotted with tawny brown, smaller than those of the Nighthawk. This nest, I believe, is the first nesting of the Whip-poor-will to be reported from Saskatchewan.

The following day photographs 


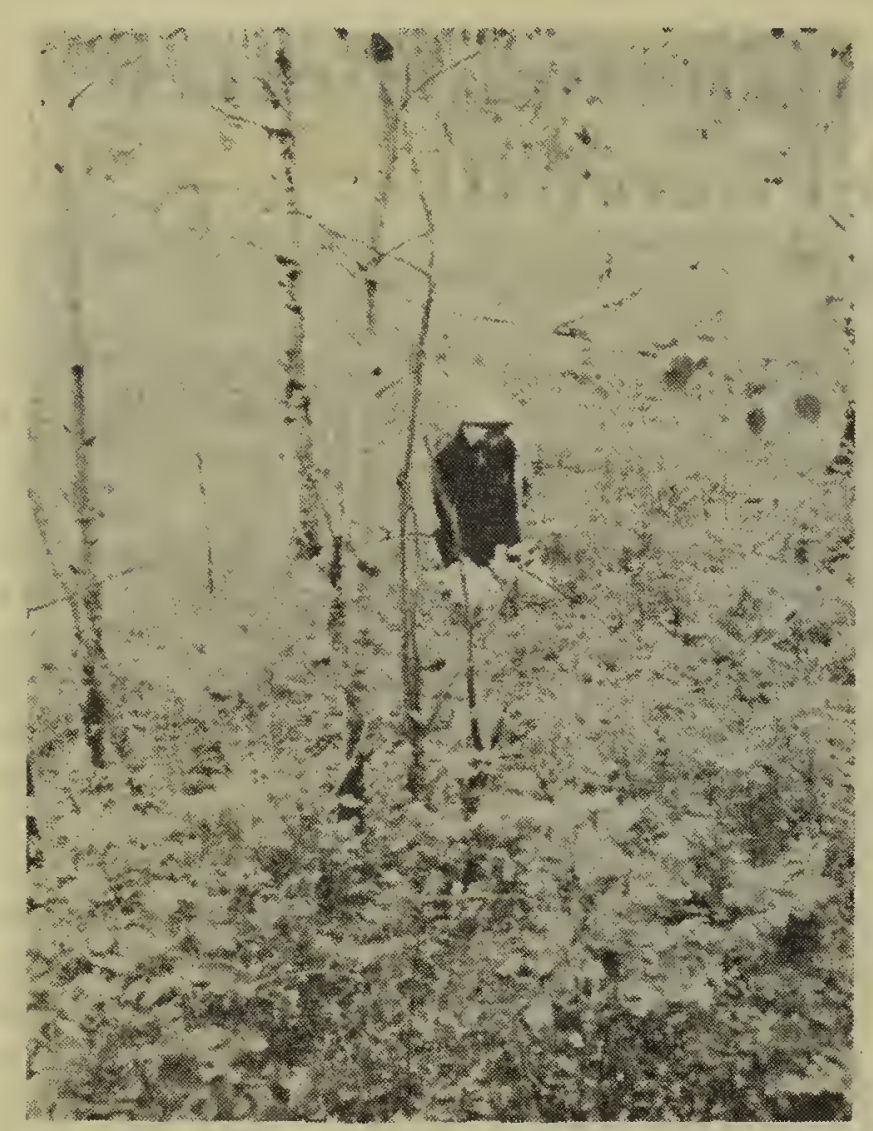

were taken of the eggs and the nestsite itself. As we approached the nest on this occasion, the male was perched lengthwise on a dead fallen branch six feet from the sitting female, in plain view; but we could not see the sitting bird until she flushed-so well did she blend with the dead leaves and the shadows cast by the surrounding trees. The male left his perch exactly when the female left her nest. The female uttered low, growling notes as she left her nest, and on each occasion

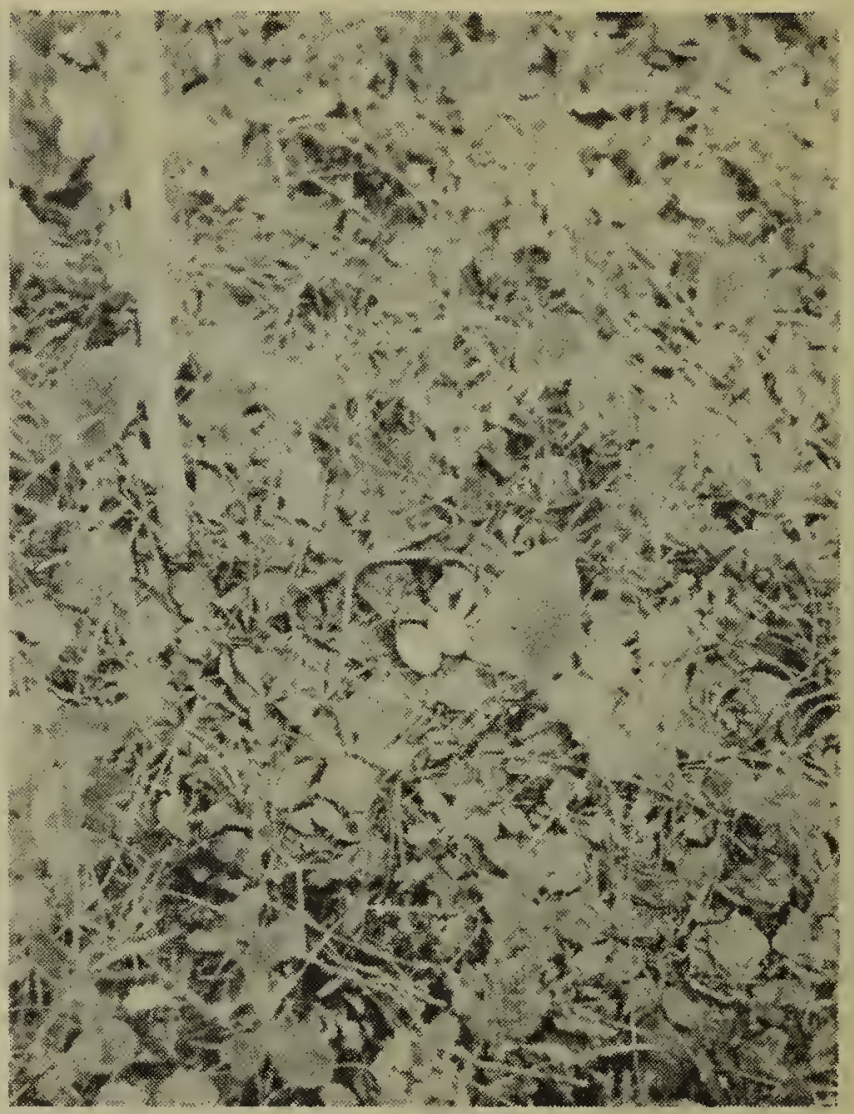

left the immediate vicinity. The exact location of this Whip-poor-will nest was the extreme south east corner of 33-51-13 W2nd.

The first young hatched July 15 th and the second probably hatched shortly after. The young were cinnamon in color. They were last seen July 27 th at the age of 12 days about 100 feet from the original nest. At this time, well grown and almost able to fly, the fledglings were banded with U.S. Wildlife Service bird bands.

\section{LITERATURE CITED}

H. H. MITCHELL - Catalogue of Saskatchewan Birds. Canadian Field-Naturalist Vol. 38; sp. No. 6, pp. 101-118, 1924.

C. STUART HOUSTON - Birds of the Yorkton District. Canadian Field-Naturalist. Vol. 63; No. 6, pp. 215-241, 1949.

RONALD and DONALD HOOPER - A preliminary list of the Birds of the Somme Distric:, Saskatchewan. Contribution No. 3, Yorkton Natural History Society, April 1954.

\section{Myrtle Warbler}

Mr. E. M. Callin who locates each new bird first by its song writes that he has heard a Myrtle Warbler singing on the grounds of the Fort Qu'Appelle Sanatorium since late May. On June 17 he set out with two others to find its nest. The nest was found 12 feet up in a Spruce. The female was sitting very close and they watched the male carry food to her as she sat on her nest. She had five eggs. Mr. Callin thinks now that a pair of Myrtles nested on the Sanatorium grounds in 1955 and he is interested in knowing if there are any other nesting records south of the Canadian Zone in Saskatchewan.

Miss Joyce Gunn, Spirit Lake, Saskatchewan writes that there are always lots of Myrtle Warblers seen in migration but this is the year that one pair has stayed to nest in the area. They nested in a Spruce close to the house and raised two young warblers and one Cowbird. They were still in the neighborhood on July' 20, 1956. 